\title{
Junior High School Students' Internal and External Problems in Speaking: A Preliminary Study of Implementing Shadowing Technique to Improve Students' Speaking Skills
}

\author{
Resky Januarty ${ }^{*}$; Abdul Asib; Suparno Suparno \\ Sebelas Maret University, Indonesia \\ Email: kiky.januarty@gmail.com
}

\begin{abstract}
This study was aimed to investigate the internal and external problems faced by the Junior High School Students in one of the schools in Indonesia. The sample in this study was the eighth grade students having low ability in Speaking. This research was a qualitative study using purposive sample. In collecting the qualitative data, the researchers did observation, interview and distributed questionnaire. This study revealed some findings related to the students' low ability in speaking. There were some internal problems which come from the students, they were 1) the low motivation in learning English; 2) the difficulty to choose the appropriate words in oral; 3) the difficulty to pronounce English words correctly; 4) the difficulty to arrange words in the appropriate order; 5) the difficulty to use sentences in appropriate grammar in oral communication; 6) The tendency to be passive learners in classroom activities; and 7) the students' low confidence in speaking. Meanwhile, the external problems come from the teacher and class situation, they were 1) the teacher didn't use alternative methods and techniques in teaching learning process: 2) the classroom activities tended to be teacher centered; 3 ) the teacher only used the text book as the teaching material provided by the; 4) there was a low interaction between students and teacher; 5) the students didn't enjoy speaking activities; 3) only few students participated in the learning process actively. Concerning with those problems, the researchers would like to offer an alternative technique of learning speaking skill, i.e. digital based English input provision. This technique is also called shadowing technique which was originally developed as a training technique.
\end{abstract}

Keywords: Students; Speaking; Internal; External; Problem; Shadowing Technique;

\section{Introduction}

English as a communication tool has an essential role in expressing emotions, needs, thoughts, and attitude. It is important for people not only to develop intellectual, social, and emotional aspects but also to determine success in learning English as a subject learnt in school from elementary school up to universities. Recently, English becomes very substantial because it is used to communicate among people in the world in numbers of aspects, such as economics, cultures, politics, and education. 
In using English for communication, whether as a second or foreign language, speaking skill is the one which cannot be neglected due to its essential role in communication. Someone, whose English is not his native language tends to encounter several problems in mastering English skill, especially for the students in high school. In Indonesia, English is considered as a foreign language (EFL). It has been introduced to educational institution as an obligatory subject. It is also one of the subjects tested in the National final examination

Based on the basic competence (KD) in the second year, 2013 curriculum, students are expected to; 1) implement the social function, text structure, and language features of written and spoken transactional texts which involve asking for and giving information related to the given contexts/action/activities/events taking place as a routine or as a general fact based on the context of use; 2) make short written or spoken transactional texts which involve asking for and giving information related to the given contexts/action/activities/events taking place as a routine or as a general fact with considering the appropriate social function, text structure, and language features based on the context of use. Students are considered to have speaking competence if she/ he is able to: 1) use correct grammatical forms (grammar); 2) produce words with correct and clear pronunciation (pronunciation); 3) use appropriate words, phrases, or utterances to express the idea (vocabulary); 4) understand the meaning in spoken texts (comprehension); 5) speak fluency with rare repetition (fluency). (Underhill., 1987; Chaney., 1996; Brown., 2004; Hughes., 2003).

There are several definitions of speaking proposed by some experts. According to Brown (2004, p. 140) speaking is an interactive process of constructing meaning that involves producing, receiving, and processing speech of sounds as the main instrument. This theory emphasizes that speaking skill is a process of producing several sounds which has particular meaning. In other words, speaking as a communication tool should involves producing, receiving, and processing speech of sounds in order to communicate each other. Everyone who speaks with someone else will try to convey meanings so that others can get the same meaning. It is called as an interactive process.

Another definition is offered by Nunan (1991, p. 39) who defines speaking as productive aural/oral skill. It consists of producing systematic verbal utterances to convey meaning. It shows that speaking activity involves oral production skill to produce meaningful utterances and meaning.

Byrne (1986, p. 8) defines speaking as a two way process between speaker and listener and involves the productive skill of speaking and the receptive skill of understanding. It means that speaking is a two way communication consists of speaking as the productive skill and understanding as the receptive skill which involves speaker and listener.

According to Chaney (1998, p. 13) speaking is the process of building and sharing meaning through the use of verbal and non-verbal symbol in a variety of context. It means that the use of verbal and non-verbal symbol is needed in the process of building and sharing meaning in various kinds of context.

Hughes (2009, p. 9) differentiates between spoken and written text into two aspects, they are: aspect of production and social aspect. Aspect of production represents aspect related to how the two forms are generated. Social aspect deals in tendencies of attitudes to the two forms. Speaking aspect production includes context dependent, unplanned, transit, interpersonal, informal, stigmatized, rhetorical, and primary.

Lewis and Hill (1993., p. 54) state that speaking is a process that covers many things in addition to the pronunciation of individual sounds. In this definition, pronunciation becomes the main subject of speaking skill. Moreover, the process of speaking covers many things to produce individual sounds. 
From the aforementioned definitions, it can be concluded that speaking is a productive aural/ oral skill between speaker and listener as an interactive process that involves producing, receiving, and processing speech of sounds through the use of verbal and non-verbal symbol in a variety of context which covers production and social aspect to convey meaning.

Furthermore, several studies have been conducted on the field of shadowing technique applied in EFL/ ESL classroom had been done by some researchers. For example Shiota (2012) whose research focused on examining the effect of shadowing technique on learners' emotion. Her research looked at how shadowing affected novice college students' psychology, which was typically low on intrinsic motivation in the Grammar Translation Method and high on anxiety in the communicative approach. Her research suggested that shadowing technique could be a useful technique to solve problems in students' attitude towards second language learning.

Another research about shadowing technique was also carried out by Manseur (2014). In his research he used a mix-method study to examine the effectiveness of shadowing technique and to explore the role of shadowing technique in the development of learner's speaking skill. His research resulted in that this technique was indeed effective in improving learners' English speaking skill. The role of shadowing technique was mostly encountered to work effectively in the areas of speaking skill.

In addition, the other research taking shadowing technique as its primary issue was also undertaken by Zakeri (2014). In this research, he also examined the effectiveness of shadowing technique towards EFL learners' oral performance in terms of fluency. His research also proved that shadowing technique was effective in improving English speaking skill including its entire performance.

Furthermore, there is an action research conducted by Hamzah and Miko (2010). This action research aimed to improve the adult Japanese learners' pronunciation using shadowing technique. Five action core research cycles were implemented in this research until the learners achieved their goal. The findings revealed that the participants have improved their bid for better English pronunciation. They have also learned how to pronounce individual words as well as English sentences rhythmically. The improvement as a result of using shadowing technique in this study as the classroom instruction can be seen in four main areas, namely: changes in the natural rate of speech, comprehension, involvement in shadowing, and confidence.

Tanwahyuni (2014) conducted a classroom action research using shadowing technique in enhancing students' listening ability in recognizing words. She applied three cycles which consist of planning, action, observing, and reflecting. Based on her research findings, she concluded that the use of shadowing technique can improve the students' listening ability particularly in recognizing words. The mean score in pre-test (50.69) is much increased in post-test (74.62). This finding also showed that the students' attitudes toward listening skill especially listen to the native English speaker also becomes better.

\section{Methodology}

This research is a qualitative study using purposive sampling. It is aimed in investigating the internal and external problems faced by the Junior High School students in mastering speaking skill. Twenty students in one of the Junior High Schools in Indonesia were involved as a sample in this research. The sample consist of 10 boys and 10 girls at the eighth grade which consider as the class with the lowest score in speaking skill and the mean score is below the passing grade. 
The researchers used performance test, interview, and questionnaire in collecting the data. The performance test is used to know the students' mean score. Interview and questionnaire are used to know the internal and external problems. Furthermore, the researcher analyzed the data based on Creswell theory. The analysis of the data was done in the following steps: collecting the data from twenty participants, classifying the data by coding to generate the setting and people, selecting/ displaying the data to make it easier in analyzing and interpreting the data which is involved interpretation or meaning of the data. In addition, the researcher interpreted by adopting the interactive model by Miles and Huberman (2014).

\section{Result and Discussion}

The study revealed that the students have a low ability in speaking. It was shown by the pre-test result which was shown that the mean score of the students is 57 from the passing grade 77 . The fact from the pre-test was that the mean score is lower than passing grade. The result of the students' pre-test in speaking showed that their score is under the minimum score of speaking. Based on the data, the highest score was 65 and the lowest score was 35 . It is shown from Table 1.

Table 1 Students mean score

\begin{tabular}{ccccccccc}
\hline No & Name & P & G & C & F & V & Total & Mean score \\
\hline $\mathbf{1}$ & AK & 59 & 60 & 61 & 53 & 60 & 293 & 58.6 \\
$\mathbf{2}$ & AS & 40 & 40 & 32.5 & 32.5 & 32.5 & 177.5 & 35.5 \\
$\mathbf{3}$ & ER & 41 & 35 & 40 & 30 & 30 & 176 & 35.2 \\
$\mathbf{4}$ & FB & 61 & 59 & 60 & 50 & 55.5 & 285.5 & 57.1 \\
$\mathbf{5}$ & MA & 59 & 56 & 60 & 53 & 60 & 288 & 57.6 \\
$\mathbf{6}$ & MR & 60 & 56.5 & 62.5 & 50 & 55 & 284 & 56.8 \\
$\mathbf{7}$ & MF & 58 & 61 & 60 & 55.5 & 55 & 289.5 & 57.9 \\
$\mathbf{8}$ & RS & 63.5 & 60 & 60 & 53.5 & 60 & 297 & 59.4 \\
$\mathbf{9}$ & RP & 62 & 60 & 60 & 53.5 & 60 & 295.5 & 59.1 \\
$\mathbf{1 0}$ & SP & 40 & 35 & 40 & 30 & 37.5 & 182.5 & 36.5 \\
$\mathbf{1 1}$ & AR & 65 & 69 & 62.5 & 56 & 63 & 315.5 & 63.1 \\
$\mathbf{1 2}$ & FA & 64.5 & 68 & 62.5 & 56 & 60 & 311 & 62.2 \\
$\mathbf{1 3}$ & HV & 65 & 70 & 62.5 & 55 & 62 & 314.5 & 62.9 \\
$\mathbf{1 4}$ & JU & 63 & 75.5 & 62.5 & 52 & 62 & 315 & 63 \\
$\mathbf{1 5}$ & LU & 68 & 72 & 58 & 53 & 62 & 313 & 62.6 \\
\hline $\mathbf{1 6}$ & MI & 65 & 65 & 60 & 55 & 60 & 305 & 61 \\
\hline $\mathbf{1 7}$ & MN & 65 & 68 & 60 & 55.5 & 62 & 310.5 & 62.1 \\
\hline $\mathbf{1 8}$ & NP & 68.5 & 72.5 & 60 & 60 & 65 & 326 & 65.2 \\
$\mathbf{1 9}$ & NA & 65 & 66 & 55 & 56 & 62 & 304 & 60.8 \\
\hline $\mathbf{2 0}$ & RK & 69 & 64 & 56 & 58 & 63.5 & 310.5 & 62.1 \\
\hline & Total & 1202 & 1213 & 1135 & 1018 & 1127 & 5693.5 & 1138.7 \\
\hline & Mean & 60.08 & 60.63 & 56.75 & 50.88 & 56.35 & 284.68 & $\mathbf{5 6 . 9}$ \\
\hline & & & & & & & & \\
\hline
\end{tabular}


The study resulting in mean score lower than passing grade implied that a majority of students have difficulties in fulfilling several important indicators of speaking skill, as most students have difficulties in: 1) producing correct pronunciation; 2) using grammatically correct forms; 3) speaking fluently; 4) mastering vocabulary; and 5) understanding the meanings.

The causes of problems derived from several aspects: from students' side, teacher side, and class situation side. In this study, the researchers also gave questionnaire and interview to the students to probe into some influential factors regarding students' low ability in speaking. The result of the questionnaire and interview revealed that the causes of problems emerging from students as the internal problems were: 1) the low motivation in learning English especially speaking because they felt that English is difficult and it is not their native language; 2) the difficulty to choose the appropriate words in oral communication because they had limited English vocabulary; 3) the difficulty to pronounce English words correctly because they didn't have enough opportunities to practice pronouncing English words; 4) the difficulty to arrange words in the appropriate order, because they transferred word by word from their native language; 5) the difficulty to use sentences in appropriate grammar in oral communication because they didn't have enough opportunities to practice; 6) The tendency to be passive learners in classroom activities because they were not interested in learning English; and 7) the students' low confidence in speaking because they felt that they didn't have adequate skill in English and didn't know how to express their idea.

On the other hand, the causes of problems from the teacher's side and class situation as the external problems showed that: 1) the teacher didn't use alternative methods and techniques in teaching learning process: 2) the classroom activities tended to be teacher centered (The teacher didn't give enough opportunities to the students to participate in the learning process, especially in the speaking activities); 3) the teacher only used the text book as the teaching material provided by the school. She didn't use other resources that can motivate the students to get engaged in the learning process, such as video or audio recording. In addition, the causes of problems from the class situation indicated that: 1) there was a low interaction between students and teacher; 2) the students didn't enjoy speaking activities; 3) only few students participated in the learning process actively.

Concerning with the students' low ability in speaking as the problem, the researchers would like to offer an alternative technique of learning speaking skill, i.e. digital based English input provision. This technique is also called shadowing technique which was originally developed as a training technique which has gained much interest among language educators in improving the listening and speaking competence of learning as 'shadowing' requires competence in both listening and speaking (Yajima., 2001, p. 29). Furthermore, according to Shiki et al. (2010, p. 82) shadowing is another immediate process of repeating speech, while repeating is an off-line task because it provides learners with silent pauses in which to reproduce the sounds they have heard. Most of the surveys available on the effects of the shadowing that have been carried out to improve listening skills give a positive influence on oral production as well. In this sense, since speaking skill is one of the competences which will be developed by this technique, it is convenient to apply it for improving student's speaking skill in this research.

The fundamental theory of shadowing technique is embedded an information-processing model propagated by McLaughin (1978) in Hamzah \& Miko (2010, p. 203) who views second language learning as two performance behaviors including controlled process and an automatic process that form the theoretical basis for the 'shadowing' technique. He explains the processes as follows: the learners first begin slowly, haltingly, sometimes with a great deal of conscious awareness and then, in course of time, they are able to automatize the whole process and execute the relevant programs and routines swiftly and without reflection.

In addition, Tamai (2002, p. 181) defines shadowing technique as an act or a task listening in which the learner tracks the heard speech and repeats it as exactly as possible while listening attentively 
to the in-coming information. Baddeley (1986) in Zakeri (2014, p. 22) proposes a Working Memory Model that illustrates clearly the mechanism of retaining memory and recognizing sounds. Practically in the context of teaching and learning speaking through shadowing technique, Kurata (2007) provides the procedure of applying this technique where the implementation ranged into: full shadowing, slash shadowing, silent shadowing, part shadowing, parts shadowing + comment, and parts shadowing + questions.

Shadowing technique seems effective and applicable to be used for improving students' speaking skill since its concept is powered by the notion of working memory model to promote the acquisition of English speaking. In accordance with the phenomena encountered in this research and the essence of shadowing technique, the researcher proposes shadowing technique to improve students' speaking skill in order to solve the students' low ability in speaking faced by the eighth grade.

\section{Conclusion}

In dealing with the aforementioned internal and external problems faced by the students at the eighth grade in a Junior high school, the researcher will conduct a further research in enhancing students' speaking skill through shadowing technique. This study is expected to give a huge contribution in English language teaching, especially in recognizing the problems faced by the students in speaking.

\section{Acknowledgment}

This research work is supported by Indonesia Endowment Fund for Education Scholarship (LPDP). I would also thank to the anonymous L2 learners for responding to the research. My big thank also delivered to the lecturers of Sebelas Maret University, Indonesia who support and give many contributions to the completion of this research.

\section{References}

Byrne, D. (1986). Teaching oral English: Longman handbooks for English teacher.

Brown, H. D. (2004). Language assessment: Principles and classroom practices. Allyn \& Bacon.

Chaney, A. L., \& Burk, T. L. (1998). Teaching Oral Communication in Grades K-8. Allyn and Bacon, Order Processing, PO Box 11071, Des Moines, IA 50336-1071.

Hamzah Md Omar, M., \& Miko, U. (2010). Using'A shadowing'technique'to improve english pronunciation deficient adult Japanese learners: An action research on expatriate japanese adult learners. Journal of Asia TEFL, 7(2): 199-230.

Hughes, Arthur. (2003). Testing for Language Teachers. Cambridge: Cambridge University Press.

Hughes, Rebecca. (2009). English in Speech and Writing: Investigating Language and Literature. London: Rouledge.

Kurata, K. (2007). A basicresearch on cognitive mechanism of shadowing. Bulletin of the Graduate School of Education, Hiroshima University, 56(2): 259-265. 
Lewis, M., \& Hill, J. (1992). Practical techniques for language teaching (pp. 39-55). Hove, England: Language teaching publications.

Manseur, R. (2014). Exploring the Role of Shadowing in the Development of EFL Learners' Speaking Skill: A Case Study of Third Year Students of English at Mohamed Kheider University of Biskra.

Miles, M. B., \& Huberman, A. M. (2014). Qualitative data analysis. Thousand Oaks: SAGE.

Nunan, D. (1991). Methods in second language classroom-oriented research. Studies in second language acquisition, 13(2): 249-274.

Shiota, K. (2012). The effectiveness of shadowing on students' psychology in language learning. Journal of Accents Asia, 5(1): 71-83.

Tamai, K. (2002). On the effects of shadowing on listening comprehension-Keynote lecture at the 3rd Annual Conference of JAIS. Interpretation Studies, 2: 178-192.

Tanwahyuni. (2014). Enhancing Students' Listening Ability in Recognizaning Words Using Shadowing Method (A Classroom Action Research at the Eighth Grade of SMP Negeri 1 Rasau Jaya, District of Kubu Raya, West Kalimatan in the Academic Year of 2013/2014). Surakarta: Pascasarjana Universitas Sebelas Maret.

Underhill, N. (1987). Testing spoken language: A handbook of oral testing techniques. Cambridge University Press.

Zakeri, E. (2014). The Effect of Shadowing on EFL Learners' Oral Performance in Term of Fluency. International Journal of English Language Teaching, 2(1): 21-26.

\section{Copyrights}

Copyright for this article is retained by the author(s), with first publication rights granted to the journal.

This is an open-access article distributed under the terms and conditions of the Creative Commons Attribution license (http://creativecommons.org/licenses/by/4.0/). 